\title{
Poetic Aesthetics in Chinese Contemporary Jewelry Design
}

\author{
Pingfei $\mathrm{Li}^{1, *}$
}

\author{
${ }^{1}$ Jilin University of Arts, Changchun, Jilin, China \\ *Corresponding author. Email: $871963052 @ q q . c o m$
}

\begin{abstract}
Taking the poetic aesthetics in contemporary jewelry design as the breakthrough point, the analysis is carried out from the three aspects of physical environment, situational conception, and artistic conception respectively, and the potential influence of poetic aesthetics in the jewelry design process is explored to find a new way for contemporary Chinese jewelry design, which can not only demonstrate the oriental wisdom but also meet the aesthetic needs of modern people.
\end{abstract}

Keywords: Poetry, Jewelry design, Physical environment, Situational conception, Artistic conception.

\section{INTRODUCTION}

Poetic sentiment occupies a very important position in Chinese traditional culture, and has guided the trend of Chinese traditional culture and art with unshakable influence. It is rooted in the gene and plays a role imperceptibly. The fastmoving modern society, the realistic and busy crowd, and the indifferent and rigid design are full of today's life. Society needs aesthetic guidance, people need emotional touch, and works need sophisticated technology. Jewelry design began to pay attention to emotional care and humanity care, pursuing poetic design closer to the soul.

\section{LITERATURE REVIEW}

Traditional China is a country of poetry, and the aesthetic thoughts in poetry dominate the spirit of traditional Chinese art. However, with the internationalization and integration, this cultural characteristic has gradually faded. In recent years, with the revival of nationality and the powerful gene of poetic culture, scholars and artists in China and foreign countries have increasingly deepened the discussion on the relationship between poetic aesthetics and design. Tang Su's article "Haze Diamond Rings: The Poetry and Design of Dutch Designers" has discussed the philosophical problems caused by the borrowing of physical images from the perspective of poetic aesthetics. Shen Yiqian of Chang'an University published an article titled "The Poetry of Materialization: Exploring the Artistic Beauty of Jewelry Art", which mainly discussed the modeling and thinking of poetic aesthetics in jewelry design. In "The Application of Aesthetic Elements of Landscape Paintings in Song Dynasty in Jewelry Design", Xu Wenjia of China University of Geosciences used the method of comparative analysis to introduce the application of the aesthetic characteristics and aesthetic elements of landscape paintings of Song Dynasty in modern jewelry design, which was of strong guiding significance for the jewelry design practice. On the whole, contemporary designers have realized the practical significance of poetic aesthetics. However, in jewelry design, there are few academic researches on poetic design and the design at the methodological level.

First of all, it is necessary to define the concept of jewelry. Jewelry, ornaments on the head, can be used by both men and women. According to "Shuowen . Jin Bu", "ornament refers to the jewelry." In Yan Shigu's note, " 襐 " means ornaments, namely, the jewelry is placed behind the two ears." Later, it mainly refers to women's headwear, arm bracelet, rings and so on, commonly known as jewelry.

If the ancient rock paintings of primitive people have witchcraft and utilitarianism, the jewelry, "one of the art works closest to human body", shows the pursuit of beauty when human beings wake up from the ancient times. In the New Cave Man site in 
Beijing (about 200000 years ago), bone fragments with polishing mark were unearthed. In the Upper Cave Man era (about 18000 years ago), chain ornaments were well made. It is because of this innate life instinct that jewelry art has made continuous progress with the development of human history, leaving an indelible mark in the evolution of human history.

The first page for Chinese literature is poetry. "The Book of Songs", the first collection of Chinese poetry, has a lot of sentences on ornaments. It is said in the "Biography" that the processing of bone utensils can be regarded as cutting, the processing of ivory can be regarded as polishing, the processing of jade polish as carving, and the processing of stone polish as grind. In only four words, four kinds of materials and techniques are involved. There is a sentence in the second paragraph of "Qi'ao", "the ears are adorned with earring, liking the stars." In "The Book of Songs · Zheng · Zijin", an ornament worn as a pendant at the waist in ancient times is used to show the yearning for love. This is the description on the ornament of the body again. Since the birth of "The Book of Songs", poets of all dynasties have paid poetic attention to jewelry. Jewelry presents aesthetic feeling, and poets infuse poetry into jewelry. With the development of history, there is deep relationship between the two. And jewelry has become images in poetry. With the poetry, jewelry has been beyond the material itself, and has a deeper connotation. For example, when it comes to jewelry, people will think of the double-bead hawksbill hairpinin the poem "Thinking" and golden Buyao (hair accessory) mentioned in Bai Juyi's "Everlasting Regret". Jewelry can be said to be poetic.

Unfortunately, jewelry is a kind of poetic existence, but this is in the past tense. The main reason why it is said to be in the past tense is that in the 1960s and 1970s, under the influence of the industrial revolution, the simplicity and precision is advocated, and people pursue the characteristics suitable for industrial reproduction. Then, the "rational design" of combining mechanical aesthetics with modern mass production is formed. With the great influence of this concept, tall buildings can be mass built, and small jewelry can also be mass produced. The rigid and massproduced products have almost no artistry except for the material of gold and silver jewelry. "Rational design" has brought people the direct and convenient characteristics, but with the improvement of the quality of material life, human beings gradually tend to pay attention to the spiritual world, and people begin to question the indifference and rigid rational standard. Some artists also began to reflect, and their works began to show human care, emphasizing personal style, creating a precedent of contemporary jewelry design. They challenge to combine all kinds of materials. With experimental creation and artistic thinking, hand-made jewelry becomes a kind of media to express personal thinking, and even reflect the society. The design concept tends to be personalized and diversified, pursuing free and poetic beauty. It is hoped that through the research on the works of some contemporary Chinese jewelry artists, people can look back at the tradition from the perspective of the world, sort out the traditional context with oriental poetic aesthetics, interpret the meaning of their works, transform their spirit into modern jewelry design language, and explore how to improve Chinese local design in the jewelry design industry worldwide.

\section{PHYSICAL ENVIRONMENT: THE APPRECIATION OF NATURE}

Throughout history, craftsmen and designers have been inspired by the worship of nature. "Seeing the traces of the hoofs of birds and animals, we can know the difference between the two. The contract can be made." The pictograph of Chinese characters begins with the imitation of nature. Most of the traditional Chinese decorative patterns are imitations of animal and plant forms in nature, which are extracted from nature through human design.

Wang Ziting's work "dim lights" draws inspiration from nature. Whenever the festival comes, the trees on the roadside will be surrounded by colorful lights, and colorful lights will wrap around the crown and body of the trees, bringing people the joy of the festival. Such a scene touched her. If the lamp itself is on the pine tree, the pine branches will not be evergreen in all seasons. With the scene of colorful lights fading, the work is born. Ordinary trees become poetic with the designer's fantastic ideas.

In his "summer fantasy", Zhu Wenjun describes such a natural scene: under the golden sunset, the sunflower fruit is beginning to mature, and the birds gather. In the harmonious picture, petals are birds, birds are petals. Is it a bird or petal? It is not important, but the symbiotic relationship between birds and plants. 
Jewelry designer Li Yi has a different poetic expression of nature. She thinks that nature brings her inner stability, indifference, quietness and purity, which is the core of oriental art. Therefore, when she expresses the nature, the material she chooses is buffalo horn. And this material represents that it will grow and die naturally. The form she expresses is flower and fruit, and it will grow and die naturally. In a reincarnation of spacetime, the internal life is revealed. In a certain period of time, regardless of being organic and inorganic, it is an external perspective used by $\mathrm{Li}^{\mathrm{Y}} \mathrm{i}^{\prime}$. Combining with philosophical vocabulary, people can see insight into the interior of nature. And a hidden paradox of growth and death can be expressed. Inadvertently, it reflects the Confucian view of the unity of all things, namely, the disappearance and the occurrence of nature.

From the above cases, one of the inspiration sources of jewelry design is the appreciation of nature. Of course, this kind of appreciation is influenced by poetic aesthetics. According to Chuang Tzu, "there is the great beauty between heaven and land, and there are laws of things. And the sage knows the laws and the beauty of nature." That is to say, the beauty of nature is the source of all kinds of beauty, which also represents the attitude of Eastern literati towards nature. Poetic aesthetics pursues the ideal state of harmonious coexistence between man and nature. As Buddha said, "A flower is a world, a leaf is a bodhi." In the form of nature, it contains poetic inspiration and understanding of life.

\section{SITUATIONAL CONCEPTION: THE APPRECIATION OF FEELINGS}

Jewelry design pursues the people-oriented and emotional conception.

The things around can often bring people different imagination, repose people's poetic feelings, and give people inspiration for design. It is either from a seed, a dream, a poem, a painting, or an insignificant object.

Chen Yingzhen's work "Dandelion's journey to the moon" is inspired by dandelion. When the dandelion seeds mature, it is also the time to leave home. When seeds leave home, they feel that the outside world is broad and mysterious, so they can't wait to leave. However, as time goes by, people suddenly find how luxurious it is to go home. So, there is a bayonet on the structure of this brooch.
The diamond needle will fall off and fall out of the body under the action of gravity according to the different posture of the wearer. But because of the bayonet, it can't fall down. Therefore, remembering to go home is the emotion to be conveyed by this jewelry.

Wang Min's work "flowers in the dust" is inspired by the young girl in Alfonso Musha's painting works. What he feels from the work is that behind the flowers and wedding dress, the young girl can lower herself for love, cherish love, and feel very happy. She is willing to lower herself, and willing to give up everything for love. As Zhang Ailing said, after meeting him, she became very low, but she was happy. And flowers came out from the dust, which was the so-called love and growth. This work is endowed with emotion and life by the author. It is like a sad poem, making people feel sad.

Che Jiayan's "Amulet" is inspired by all kinds of amulets popular on the Internet. Amulet comes from Chinese Taoism, which is a kind of virtual and suggestive symbol. The author wants to design her own "amulet", which can give her some psychological hints. She explained her original intention in this way: there is a special way of communication between my mother and I writing. My mother's love and encouragement have always been the strength to support me and make me believe in myself at every moment when I doubt myself. It is the power that exists in my heart, which becomes my spiritual pillar and supports me silently. I want to visualize this "power" by making jewelry. Letters are the external communication bridge between my mother and I. I put the symbol of letters in jewelry as my "talisman". This work is full of aura.

Tian Zejun's jewelry design named "phantom" is inspired by Zhuang Zhou's dream in "Chuang $\mathrm{Tzu} \cdot \mathrm{Qi} \mathrm{Wu}$ ". Such a poetic work originates from the combination of dream and design. Butterfly fish is colorful, swimming freely in the sea, being elegant and flexible. According to butterfly fish, people can feel a hint of complacency.

As can be seen from the above, jewelry is not only an ornament, but also a handicraft reflecting skills. In jewelry design and creation, it should strive to break the traditional concept that jewelry is only used as wearing goods by expressing the deep meaning. In fact, the most moving part of the work is not the complicated combination of shapes, but the ideas people have been trying to convey 
through jewelry are poetic feelings, such as love, faith and life. Design works with context as the source often make people feel the poetic resonance in their heart.

\section{ARTISTIC CONCEPTION: THE GRASP OF PHILOSOPHY}

Qian Zhongshu once pointed out in the book "Art": "the so-called artistic conception is to see the consistent with one of the differences." That is, through concrete description, it reveals objective philosophy, and the poetic flavor is strong, that is, the philosophy that poetry produces.

In the contemporary jewelry art, jewelry not only refers to the physical jewelry, but also refers to the historical and social concept of jewelry, which is an expression of the examination, reflection and criticism of the times and society.

According to Yuan Jianqing's "tainted spectacles", it has made a good interpretation of this concept. His thinking angle is extraordinary, and the visual language is concise and accurate, expressing that people all wear colored glasses, so most people see what they want to see. His works not only have poetic philosophy, but also have strong artistic criticism function.

For example, Wu Mian's "as light as soul and as heavy as soul" is the work during the epidemic this year. She made a balloon with glass, expressing her thinking about life in a perceptual and poetic way. She took "soul $21 \mathrm{~g}$ " as the starting point, reflecting the deep meaning of "being from jewelry to jewelry". It has strong realistic significance.

Professor Wang Xiaoxin of Academy of Art in Tsinghua University is good at combining Chinese traditional culture, which is not limited to symbolic appearance, and conveys the core of oriental philosophy in the form of art. His works pay more attention to publicity and social relations, and boldly adopt the compatibility of modern science and technology and traditional handicrafts. With the disc as the carrier, the work "the same and the different" shows many identical individuals, just like the individuals in the modern society who tend to be the same day by day. Their eyes and thoughts point to different directions. Many individuals are combined to form a harmonious form of Chinese traditional jade, forming a "Great Harmony" that embraces all differences. His works are full of fusion and speculation.
Through the interpretation of the above works, it can be seen that artistic conception is naturally revealed through the poetic image. These design works with philosophy often originate from the author's philosophical perception of objects, with strong speculative.

\section{CONCLUSION}

To explore the poetic aesthetics of Chinese contemporary jewelry works is to find a romantic and touching temperament in design, a design language different from mechanical engineering and rationality, and to find a thinking method of integrating design with art. In today's world, it is required to be neither complacent nor self-belittling. With Chinese poetic aesthetics, it is suggested to constantly make the exploration in the field of jewelry design and give full play to the value. Therefore, it can embark on a poetic road of jewelry design.

\section{AUTHORS' CONTRIBUTIONS}

This paper is independently completed by Pingfei Li.

\section{REFERENCES}

[1] Yuan Yu'an's translation of poems, Tang Moyao's annotation: "The Interpretation of the Book of Songs", Guizhou People's Publishing House, June 1981, p. 114. (in Chinese)

[2] Yu Guanying. "Selected Translations of the Book of Songs", People's Literature Publishing House (first edition), December 1958, second printing in Hubei, November 1978, p.35. (in Chinese)

[3] Zhai Mo. "Seven Songs of Academics", "Friends of Fine Arts", No.2, 2006. (in Chinese)

[4] Zong Baihua. "Art World", Peking University Press, 1997. (in Chinese)

[5] Meng Kun. "Research on Poetic Thinking in Graphic Design", March 2011. (in Chinese)

[6] [Italian] Kim Buck, [Norwegian] Jorunn Veiteberg. "The eye-catching jewelry: Jorunn Veiteberg Interview with Kim Buck", "Design", 2017, Issue 4, p. 54-57. (in Chinese) 